\title{
Review
}

\section{Protective Role of Methylene Blue in Alzheimer's Disease via Mitochondria and Cytochrome c Oxidase}

\author{
Hani Atamna* and Raj Kumar \\ Department of Basic Sciences, Neuroscience, The Commonwealth Medical College, Scranton, PA, USA
}

Accepted 15 April 2010

\begin{abstract}
The key cytopathologies in the brains of Alzheimer's disease (AD) patients include mitochondrial dysfunction and energy hypometabolism, which are likely caused by the accumulation of toxic species of amyloid- $\beta$ (A $\beta$ ) peptides. This review discusses two potential approaches to delay the onset of AD. The first approach is use of diaminophenothiazines (e.g., methylene blue; $\mathrm{MB}$ ) to prevent mitochondrial dysfunction and to attenuate energy hypometabolism. We have shown that MB increases heme synthesis, cytochrome $c$ oxidase (complex IV), and mitochondrial respiration, which are impaired in AD brains. Consistently, MB is one of the most effective agents to delay senescence in normal human cells. A key action of MB appears to be enhancing mitochondrial function, which is achieved at $\mathrm{nM}$ concentrations. We propose that the cycling of MB between the reduced leucomethylene blue $\left(\mathrm{MBH}_{2}\right)$ and the oxidized $(\mathrm{MB})$ forms may explain, in part, the mitochondria-protecting activities of MB. The second approach is use of naturally occurring osmolytes to prevent the formation of toxic forms of A $\beta$. Osmolytes (e.g., taurine, carnosine) are brain metabolites typically accumulated in tissues at relatively high concentrations following stress conditions. Osmolytes enhance thermodynamic stability of proteins by stabilizing natively-folded protein conformation, thus preventing aggregation, without perturbing other cellular processes. Experimental evidence suggests that the level of carnosine is significantly lower in $\mathrm{AD}$ patients. Osmolytes may inhibit the formation of $\mathrm{A} \beta$ species in vivo, thus preventing the formation of soluble oligomers. Osmolytes are efficient antioxidants that may also increase neural resistance to $\mathrm{A} \beta$. The potential significance of combining $\mathrm{MB}$ and osmolytes to treat $\mathrm{AD}$ are discussed.
\end{abstract}

Keywords: Alzheimer's disease, amyloid- $\beta$, heme, methylene blue, mitochondria, osmolytes, oxidase, peroxidase

\section{INTRODUCTION}

Alzheimer's disease (AD) is a progressive dementia marked by failure to form new memories, thus interfering with the patient's normal daily activities. AD is the most common age-related dementia manifested by widespread progressive cognitive deterioration and impaired behavioral skills. The cost of caring for $\mathrm{AD}$

\footnotetext{
* Correspondence to: Hani Atamna, Department of Basic Sciences, The Commonwealth Medical College, Tobin Hall, 501 Madison Avenue, Scranton, Pennsylvania 18510, USA. E-mail: hatamna @ tcmedc.org.
}

patients is staggering, and in the US exceeds $\$ 100$ billion annually. Current drugs for AD can only remedy the symptoms with little or no effect on the basic mechanisms underlying the disease.

The most accepted view for the pathological mechanism of $\mathrm{AD}$ is the accumulation of small peptides known as amyloid- $\beta(\mathrm{A} \beta)$ in the brains of $\mathrm{AD}$ patients [1]. $\mathrm{A} \beta$ are the product of the proteolytic processing of a larger protein known as the amyloid- $\beta$ protein precursor $(\mathrm{A} \beta \mathrm{PP})$. Three different proteases can cleave $\mathrm{A} \beta \mathrm{PP}$ at three different locations. These proteases are designated as $\alpha-, \beta$-, and $\gamma$-secretases. The cleavage of $\mathrm{A} \beta \mathrm{PP}$ by $\beta$ - and $\gamma$-secretases is consid- 
ered amyloidogenic cleavage because it produces intact $\mathrm{A} \beta$ peptide. If $\mathrm{A} \beta \mathrm{PP}$ is cleaved by $\alpha$-secretase, $\mathrm{A} \beta$ does not form and the cleavage is considered nonamyloidogenic. Interestingly, the sites of the proteolytic cleavage of A $\beta$ PP by $\gamma$-secretase can vary. $\gamma-$ secretase cleaves at several adjacent sites to create the c-terminal of $\mathrm{A} \beta$. Thus, various $\mathrm{A} \beta$ species containing 39-43 amino acid residues are produced [2]. The cleavage of A $\beta$ PP by $\gamma$-secrtetase increases with age and in response to specific risk and genetic mutations, increasing the production of the long species of $\mathrm{A} \beta[3-$ $6]$. We will collectively refer to all the forms as $\mathrm{A} \beta$.

The long species of $\mathrm{A} \beta\left(\mathrm{A} \beta_{42,43}\right)$ are strongly amyloidogenic and aggregate more readily than the short form of $\mathrm{A} \beta\left(\mathrm{A} \beta_{39,40}\right)$; thus, they may provide the nucleation seed for the formation of $\mathrm{A} \beta_{40}$ aggregates, which ultimately are the building blocks for the senile plaques formation [7]. Senile plaques are insoluble extracellular $\mathrm{A} \beta$ deposits, in which $\mathrm{A} \beta$ forms insoluble fibrils. Senile plaques are one of the neuropathological hallmarks of $\mathrm{AD}$ mainly made from $\mathrm{A} \beta$ peptides; however, other proteins can also be detected in senile plaques but at very low abundance [7].

In addition to the oligomeric and fibril forms of $\mathrm{A} \beta$, studies have shown that $\mathrm{AD}$ is also marked by neurofibrillary tangles and other key cytopathologies (reviewed in [8]). Some of the key cytopathologies in AD include decline in cytochrome $c$ oxidase (complex IV), mitochondrial dysfunction, and energy hypometabolism. The molecular link between $\mathrm{A} \beta$ and the key cytopathologies of AD is still debated [9-12]. In the following sections, we will discuss each of these elements, and new views into $\mathrm{A} \beta$ neurotoxicity and delaying the onset of AD.

\section{AMYLOID- $\beta$, OLIGOMERS, AND FIBRILS}

Because of the natural tendency of $\mathrm{A} \beta$ to form oligomers, aggregates, and senile plaques, AD is defined as a disorder of protein aggregation and misfolding. The factors that trigger protein misfolding in vivo and with age are not yet clear. However, genetic polymorphism, as well as environmental and lifestyle factors may be important risk factors for $\mathrm{A} \beta$ peptide accumulation and aggregation [3-6].

Several lines of research show that an increase in soluble dimeric and oligomeric forms of $\mathrm{A} \beta$, which precede the appearance of senile plaques [13-15], correlate with early cognitive impairment in $\mathrm{AD}[16,17]$. Furthermore, experiments using cultivated cells, trans- genic mouse models for AD, and human brain autopsy tissue suggest that soluble $\mathrm{A} \beta$ oligomers are likely the primary toxic forms of $\mathrm{A} \beta$. $\mathrm{A} \beta$ oligomers are also elevated in human- $\mathrm{A} \beta \mathrm{PP}$ transgenic mice for $\mathrm{A} \beta$ accumulation and AD [18] and most significantly, in $\mathrm{AD}$ brain [19]. Thus, preventing the aggregation of $\mathrm{A} \beta$ peptides is a plausible approach to delay $\mathrm{AD}$. Interestingly, experimental evidence also shows that $\mathrm{A} \beta$ can be found not only at the extracellular milieu, but also inside the cell and even in the mitochondria [20, 21 ], stressing the view that intracellular $\mathrm{A} \beta$ as well as extracellular $\mathrm{A} \beta$ could also be neurotoxic [22]. This is a major departure from the older view that senile plaques are the main neurotoxic factor in AD. Senile plaques may contribute to $\mathrm{AD}$ by slowly shedding to their surrounding the soluble oligomeric form of $\mathrm{A} \beta$. Thus, methods for stabilizing senile plaques may delay the onset of $\mathrm{AD}$ by lowering the oligomeric forms of $\mathrm{A} \beta$. In this article, we propose a pharmacological approach to enhance mitochondrial function and prevent the formation of $\mathrm{A} \beta$ toxic oligomers.

It is not clear which of the key cellular compartments (i.e., cytosolic, mitochondria, synapses) is the primary target of soluble oligomeric $\mathrm{A} \beta$ toxicity. Mitochondria appears to be a target for $\mathrm{A} \beta$ toxicity as we will discuss below. Synaptic dysfunction is also proposed to be the primary neural malfunction that disturbs cortical neural circuits and causes short-term memory impairment in AD patients [23]. Synaptic dysfunction is suggested to precede neural death and appears to be the target of $\mathrm{A} \beta$ neurotoxicity. This hypothesis emerged from experiments showing that $\mathrm{A} \beta$ oligomers inhibit long-term potentiation (LTP), a classic experimental paradigm for memory and synaptic plasticity [24,25]. Impairment of energy metabolism by intraneuronal A $\beta$ inhibition of key mitochondrial functions may also contribute to synaptic dysfunction in AD. Thus, preventing mitochondrial dysfunction is an additional plausible approach to delay AD. Our goal is to identify the primary metabolic pathway that is specifically targeted by excess $\mathrm{A} \beta[26]$.

\section{COMPLEX IV, MITOCHONDRIA, AND ENERGY METABOLISM}

The key cytopathologies of AD include decline in cytochrome c oxidase (complex IV), mitochondrial dysfunction, energy hypometabolism, abnormal iron homeostasis, oxidative stress, dimerization of $\mathrm{A} \beta \mathrm{PP}$, and synaptic dysfunction [27-31]. Selective decline 
in mitochondrial complex IV seems to contribute to mitochondrial dysfunction, energy hypometabolism, and oxidative stress (e.g., increased production of $\mathrm{H}_{2} \mathrm{O}_{2}$ ) [32-34]. The molecular link of $\mathrm{A} \beta$ to these cytopathologies is not clear. Soluble oligomeric forms and intraneuronal $\mathrm{A} \beta$ could be critical for understanding the mechanism of neurotoxicity of $\mathrm{A} \beta$. We have recently proposed a new model for $\mathrm{A} \beta$ toxicity in which strong binding of $\mathrm{A} \beta$ with heme is key for the neurotoxicity of $\mathrm{A} \beta$. $\mathrm{A} \beta$ binding with heme leads to the depletion of regulatory heme and the decline in complex IV activity among other effects [35,36]. Thus, heme metabolism could be the primary metabolic pathway that is specifically targeted by excess $\mathrm{A} \beta$.

Mitochondria appear to be a direct target for $\mathrm{A} \beta$. $\mathrm{A} \beta$ peptides can be detected in the mitochondria [3739]. Furthermore, this view was strengthened because emerging evidence point to that $\mathrm{A} \beta$ may exert its toxicity, in part, by interfering with specific mitochondrial structures and functions. For example, $\mathrm{A} \beta$ may increase the production of nitric oxide (NO), which triggers mitochondrial fission (fragmentation) leading to mitochondrial damage and impaired energy metabolism [40]. S-nitrosylation of dynamin-related protein 1 (Drp1) is a possible candidate for this effect of NO. Nitrosylation of Drp1 is increased in AD brains [40]. In the same line with these findings, $\mathrm{A} \beta$ disturbs the normal balance in mitochondrial fission and fusion that leads to smaller mitochondria and abnormal intracellular distribution [41]. This, abnormal biology of the mitochondria may contribute to mitochondrial and neuronal dysfunction seen in AD [41]. The effect of $\mathrm{A} \beta$ on the permeability transition pore has also been reported. A $\beta$ 's toxicity to mitochondria seems to require $\mathrm{A} \beta$ binding with cyclophilin $\mathrm{D}$, a key component of the formation of permeability transition pore and thus regulating cell death [42].

Several studies have demonstrated changes to the TCA cycle, which is an important metabolic pathway in mitochondria, in addition to electron transport and complex IV. Researchers have demonstrated a 30-40\% decrease in complex IV activity $[43,44]$ in addition to $\alpha$ ketoglutarate dehydrogenase $(\alpha \mathrm{KGDH})$ [45]. A more comprehensive screening of the activities of the TCA cycle enzymes in $\mathrm{AD}$ revealed that some decreased (e.g., PDH, $\alpha \mathrm{KGDH}$, and ICDH), others increased (e.g., SDH and MDH), while the four other enzymes did not change (e.g., aconitase) [46]. These changes presumably would result in a decline in succinyl-CoA, the intermediate of the TCA cycle that is produced by $\alpha \mathrm{KGDH}$ and consumed by the subsequent reactions of SDH and MDH. Succinyl-CoA is the precursor for heme synthesis [47]. Thus, decline in succinyl-CoA would be expected to synergize with the consequences of $\mathrm{A} \beta$ complexing with heme and exacerbate the depletion of regulatory heme $[26,48]$. In addition to the biochemical changes, the mitochondria from the brain of AD patients exhibits substantial structural changes that included abnormal cristae, accumulation of osmiophilic material, and smaller size compared to normal controls $[21,49]$. The decline in complex IV, which occurs in heme deficient cells, leads to similar structural consequences on mitochondria (unpublished observations).

\section{AMYLOID- $\beta$ PEPTIDE BINDS WITH SPECIFIC METABOLITES}

Several studies have demonstrated an abnormal interaction of $\mathrm{A} \beta$ with key brain metabolites. $\mathrm{A} \beta$ can bind iron, zinc, copper, cholesterol, mitochondrial protein import machinery, HrtA2 protease, ABAD, and heme [20,26,37,50-52]. The biochemical and metabolic consequences of the interaction of $\mathrm{A} \beta$ and these metabolites are under investigation, especially their relation to landmark cytopathologies of $\mathrm{AD}$, such as the decline in complex IV, loss of iron homeostasis, and energy hypometabolism.

Several lines of experimental evidence provided support that heme metabolism may be a specific metabolic pathway that is targeted by $\mathrm{A} \beta$ peptides [26,53-55]. We recently showed a specific heme-binding motif in human $\mathrm{A} \beta$ peptides [26]. These findings led to the proposal that depletion of regulatory heme and the formation of $\mathrm{A} \beta$-heme peroxidase are key factors in energy hypometabolism, mitochondrial dysfunction, oxidative stress, loss of complex IV, and impaired iron homeostasis seen in the brains of AD patients (reviewed in [8]).

Heme-binding with $\mathrm{A} \beta$ could also explain why humans, but not rodents, develop AD-like neuropathology. Compared to human $\mathrm{A} \beta$ (huA $\beta$ ), amino acids Arg5, Tyr10, and His13 are replaced with Gly5, Phe10, and Arg13, respectively, in rodent $\mathrm{A} \beta$ ( $\operatorname{roA} \beta$ ) (reviewed in [8]). The phylogenic variation in the amino acid sequences of $\mathrm{A} \beta$ led to differential heme-binding between huA $\beta$ and $\operatorname{roA} \beta$. huA $\beta$ binds heme with high affinity $\left(\mathrm{K}_{d}=1.4 \times 10^{-7} \mathrm{M}\right)$, while the $\mathrm{K}_{d}$ for $\operatorname{roA} \beta$ was ten-fold less. These findings stress the significance of the three amino acids: Arg5, Tyr10, and His13 in heme-binding by huA $\beta$. The amino acids Arg, Tyr, and His are known to also participate in heme-binding 
in heme-proteins and peroxidases [56-58], which provide biochemical support for the observed peroxidase activity of huA $\beta$-heme.

huA $\beta$ is likely to bind with "regulatory" heme in vivo. The intracellular concentration of "regulatory" heme is estimated to be between 0.3 and $1.5 \times 10^{-7}$ $\mathrm{M}$ [59], indicating that huA $\beta$ is likely to form an $\mathrm{A} \beta$ heme complex in the brains of AD patients. Consistently, heme has recently been found to colocalize with the senile plaques in $\mathrm{AD}$ brain [53]. $\operatorname{RoA} \beta$, on the other hand, is far less likely to bind with heme in vivo since the $\mathrm{K}_{d}$ is higher than the concentration of regulatory heme.

Heme is the major functional form of iron and is responsible for the metabolic integrity of complex IV, the mitochondria, and the regulation of key gene regulation systems. Regulatory heme provides heme for all the biochemical pathways that depend on heme (e.g., assembly of heme-proteins, gene regulation, processing of microRNA) $[7,60,61]$. Thus, saving regulatory heme by lowering $\mathrm{A} \beta$ oligomeric forms and enhancing heme synthesis should improve neuronal energy metabolism.

\section{CURRENT THERAPEUTIC APPROACHES AND THE CHALLENGE}

Despite the intensive research on AD and the depth to which we understand the cell biology and biochemistry of $\mathrm{A} \beta$ (and to some extent $\mathrm{A} \beta \mathrm{PP}$ ), a therapy or prevention strategy for AD remains elusive [62]. The absence of a definite molecular mechanism to explain the neurotoxicity of $\mathrm{A} \beta$ is a key obstacle for the development of effective therapies to treat AD. Drugs currently available to treat AD patients (e.g., blocking NMDA glutamate receptors, acetylcholine esterase inhibitors) are targeted at treating only the symptoms of $\mathrm{AD}$ and their efficacy is also limited. The efficiency of these drugs progressively declines as the disease progresses, indicating that they do not alter the underlying neurodegenerative mechanism of $\mathrm{A} \beta$. Furthermore, these drugs also seem to be ineffective in some patients. Thus, there is an urgent need for a new generation of drugs to prevent or delay the onset of AD.

A reliable and accurate diagnostic biomarker for $\mathrm{AD}$ is also lacking. Progress is being made on this front by relying on imaging techniques, abnormal brain structures, and $\mathrm{A} \beta$ deposits [63], all of which specify the clinical aspects of the disease itself. Thus, in order to benefit from the full potential of imaging techniques, they must be accompanied by a cure for $\mathrm{AD}$, which cur- rently is not available. The ultimate biomarker would preferably be a blood- or CSF-borne metabolite that indicates the risk for AD in advance of the clinical signs. Furthermore, as is the case for imaging techniques, for such a biomarker to be utilized to its full potential, a prevention method is needed. The established mitochondrial dysfunction in AD creates an additional therapeutic route to explore possibilities to enhance mitochondrial function and delay the onset of AD. Below, we discuss a new approach to prevent the decline in mitochondrial complex IV, enhance heme production, and prevent the formation of the toxic species of $\mathrm{A} \beta$ peptide.

\section{OLIGMOERS AND MITOCHONDRIA AS TARGETS FOR DELAYING AD}

The brain is particularly sensitive to mitochondrial dysfunction, the resulting oxidative stress, and impaired energy metabolism [64-66]. Energy deficiency can result in synaptic dysfunction and neurodegeneration of the hippocampus and cortical regions of the brain [67]. A promising approach to improve the brain's energy metabolism has been shown using intranasal delivery [68] to elevate the level of insulin in the brain [69], which may improve glucose metabolism. An additional approach to improve energy metabolism is to enhance the activity of the mitochondria in the brain. Both the glucose metabolism and mitochondria are interconnected, thus an approach to improve both aspects of energy metabolism might be more effective.

Insoluble protein aggregates and misfolded protein deposits such as $\mathrm{A} \beta$ oligomers, senile plaques, phosphorylated tau (p-tau), $\alpha$-synuclein, and polyglutamine are neuropathologies in many neurodegenerative diseases. $\mathrm{A} \beta$ oligomers in $\mathrm{AD}$ usually progress to form large insoluble plaques, which exacerbate neurodegeneration, indicating that the human brain has a limited capacity of disposal of $\mathrm{A} \beta$ aggregates. Decline in proteosome activity with age may contribute to the accumulation of the misfolded protein deposits [70]. The aging brain also exhibits limited capacity of self-repair (e.g., limited neurogenesis).

Our knowledge of the kinetics of the formation of $\mathrm{A} \beta$ oligomers in vivo as well as the mechanism by which they interfere with the function of distinctive set of neurons is limited. We propose that intermediate species in the cascade of protein misfolding may become highly toxic by interfering with basic metabolic activity of the brain. We demonstrated that the binding 
of $\mathrm{A} \beta$ (and the soluble oligomers of $\mathrm{A} \beta$ ) with heme results in sequestration of regulatory heme leading to impaired cellular metabolism. Therefore, preventative approaches to treating $\mathrm{AD}$ could be targeted at blocking the formation of $\mathrm{A} \beta$ oligomers and enhancing the synthesis of heme and complex IV, in addition to the use of antioxidants.

\section{Preventing aggregation and oligmoerization of amyloid- $\beta$ with osmolytes}

Proteins need to maintain their functionally active conformation(s) under physiological conditions [71]. Thus, under severe physical and chemical stress conditions, proteins must counter-balance any significant perturbations in the thermodynamic conditions to avoid significant changes in their conformations [72-75]. Proteins failing to adapt to such conditions may result in misfolding/aggregation, which lead to a partial or complete loss of their functional activity $[76,77]$. In order to adapt to such perturbations, tissues create certain mechanisms such as accumulation of small organic solutes, also known as "osmolytes" [72,73,78]. These osmolytes maintain stability and folding of proteins without perturbing other cellular processes, and are typically accumulated intracellular at relatively high concentrations [74,75,77,79-81]. It is a well known fact that once proteins are synthesized, the highly disordered unfolded state passes through well-defined partially structured transition states to fully folded forms, aided by molecular chaperones that deter aggregation of incompletely folded species [82]. Under certain conditions, protein unfolds, at least partially, and becomes prone to aggregation [83-85]. This may result in the formation of fibrils and other possible aggregates that accumulate in tissue [86-91]. It is likely that small aggregates, as well as the highly organized fibrils and plaques, can give rise to pathological conditions, a common feature among many neurodegenerative diseases, including AD [81,92].

There are a number of well-known naturally occurring osmolytes, which fall into three chemical classes: methylamines (trimethylamine-N-oxide, CholineO-sulphate, and sarcosine), polyols (sorbitol, glycerol, sucrose, and trehalose), and certain amino acids (glycine, taurine, proline, and betaine). Some of these osmolytes are shown in Scheme 3. Each of these interacts with the peptide backbone and amino acid sidechains [93]. The potency of the osmolyte to promote protein folding and solubility is determined by the balance of these effects. There are several studies to sup- port the view that the powerful solvophobic effects of osmolytes on the peptide backbone dominate, such that the relative Gibbs free energy $(\Delta \mathrm{G})$ of the unfolded state is less favorable than that of the folded state.

The presence of several osmolytes inside cells raises questions about their roles in protecting intracellular macromolecules under pathological conditions. Since the protection provided by an osmolyte does not depend on specific chemical interactions with the macromolecules, in principle, any of the osmolytes should be capable of replacing each other, depending upon either endogenous or exogenous availability of particular osmolyte(s) [94]. Since the role of protein backbone is critical in determining thermodynamic stability and folding of proteins in osmolyte solutions [95-99], designing these small molecules (osmolytes) appears to be an excellent strategy and could be a critical step in preventing various critical proteins from misfolding or aggregating [6]. This may have far reaching consequences in understanding and preventing several deleterious diseases that are caused by protein misfolding/aggregation [100,101]. Since organic osmolytes are naturally occurring molecules, they may have potential therapeutic applications without concerns of major toxic side effects [102].

It has been shown that oral administration of an osmolyte (trehalose) can significantly inhibit polyglutamine-mediated protein aggregation in the transgenic mouse model of Huntington's disease (a neurodegenerative disease) and subsequently increase life span [98]. Another study has demonstrated that osmolytes can be used to fold androgen receptor containing elongated polyglutamine chain length, which leads to formation of protein aggregates and is responsible for a neurodegenerative disease [100]. Because of their protein stabilizing capabilities, osmolytes have been the focus of several studies related to neurodegenerative diseases in which the pathogenesis is associated with the misfolding of specific proteins [103,104]. These diseases include AD, Huntington's disease, and muscular dystrophy. In these pathological conditions, specific misfolded aggregate-prone proteins are resistant to the normal cellular processes. Insoluble aggregates are found to correlate with the progression of these diseases. Osmolytes are thought to work by interfering with the production and/or enhancing destruction of these toxic entities. Thus, osmolytes have become an attractive molecule for study in neurodegenerative diseases characterized by protein misfolding and aggregate pathology.

Osmolytes have also been found beneficial in transgenic model systems for oculopharyngeal muscular 
dystrophy, an autosomal dominant disease [105]. Despite of the fact that, in $\mathrm{AD}$, toxicity is increasingly linked to the formation of oligomeric forms of $\mathrm{A} \beta$ peptides, AD progression is correlated with increasing aggregate formation of $\mathrm{A} \beta$, like many other neurodegenerative diseases [103]. In $\mathrm{AD}, \mathrm{A} \beta_{40}$ is the most prominent peptide and $\mathrm{A} \beta_{42}$ is more toxic. It has been reported that at the physiological concentration, $\mathrm{A} \beta_{40}$ peptide incubated in the presence of an osmolyte, trehalose inhibits aggregation of this peptide in a dose-dependent manner [106]. This osmolytemediated inhibition of $\mathrm{A} \beta_{40}$ peptide aggregation correlates with its toxic effects in neuronal cell system [106]. Thus, osmolytes may have potential as part of a therapeutic strategy for treating $\mathrm{AD}$, because of their effect on $\mathrm{A} \beta$ oligomers. Osmolytes may also help stabilize the senile plaques, preventing the shedding of $\mathrm{A} \beta$ oligomers. Osmolytes are also known to function as antioxidants [107,108], and their level seems to decline in AD patients [109]. These studies suggest that naturally occurring osmolytes may have a protective effect in promoting brain health, including AD. Thus, there is potential for both prevention and treatment of neurodegenerative diseases [110,111]. The prospect of using natural osmolytes as a therapeutic tool for AD and several other neurodegenerative diseases appears to be quite exciting without fear of major side effects. However, while these studies appear to be quite promising, more studies are needed to validate their effectiveness as a potential therapeutic target. Protein aggregation/misfolding constitutes a hallmark of neurodegenerative diseases including $\mathrm{AD}$, as understanding the proper mechanism of action of osmolytes in these pathological conditions can have far reaching consequences in developing better therapeutic tools for the prevention and/or management of such diseases.

\section{Preventing the decline in complex IV with methylene blue}

Mitochondrial dysfunction in AD is marked by a decline in complex IV, decline in other TCA cycle enzymes, and mutations to mtDNA. Impairment to mitochondrial complex IV increases the production of free radicals and oxidants, such as hydrogen peroxide $\left(\mathrm{H}_{2} \mathrm{O}_{2}\right)$. Energy deficiency is an additional serious result of impaired mitochondrial function. Furthermore, the role of mitochondria in cellular senescence and aging has also been demonstrated, which may contribute to neural dysfunction with age. Mitochondrial medicine is an emerging field of research directed at finding therapeutic strategies to enhance mitochondrial function to combat aging and neurodegenerative disorders. This direction of research led to the discovery of several agents that can delay aging in human primary cells in culture or in other research models (reviewed in [112]). These agents are proposed to target basic mechanisms of aging, including mitochondria. The efficacy of these agents to delay aging in vivo is under investigation [113]. Thus, mitochondria-protecting agents may also be potential drugs to prevent or delay age-related neurodegeneration (e.g., AD).

We recently showed that $\mathrm{MB}$ is unusually effective in counteracting some key basic mechanisms of mitochondrial dysfunction [114]. MB increases mitochondrial complex IV by $30 \%$, enhances cellular oxygen consumption by $37-70 \%$, increases heme synthesis, and reverses premature senescence caused by $\mathrm{H}_{2} \mathrm{O}_{2}$ or cadmium. We showed that MB delays senescence human lung fibroblasts at nM levels. Enhancing mitochondrial function could contribute to the antisenescence activity of MB. We also found that the activity of complex IV in brain of old mice was doubled upon treatment with MB for three months [115].

The ability of MB to cross the blood brain barrier also has been demonstrated by previous studies [116]. We found that when MB is administered in drinking water to old mice for three months, the brain concentration does not exceed $120 \mathrm{nM}$ [115]. This concentration of $\mathrm{MB}$ is consistent with the $100 \mathrm{nM}$ required for optimal effect on mitochondria in vitro [114].

\section{THE SIGNIFICANCE OF INDUCING COMPLEX IV AND HEME SYNTHESIS WITH MB TO THE PREVENTION OF AD}

MB is the first chemical to be capable of inducing mitochondrial respiratory complex. MB also enhances the capacity of the cells to synthesize heme and delay cellular senescence. Thus, we propose a new medical use for MB; an agent that may postpone the onset of $\mathrm{AD}$ by delaying the decline in complex IV and increasing heme synthesis. If we assume that a critical threshold of complex IV and heme level determines the age of onset of synaptic dysfunction and energy hypometabolism in $\mathrm{AD}$, then $\mathrm{MB}$ may increase the brain's reserve of both complex IV and the capacity to synthesize heme (Fig. 1).

Increasing the activity of complex IV above normal levels is intriguing. Normally, complex IV is found in $\approx 5$ fold excess over the other electron transport com- 


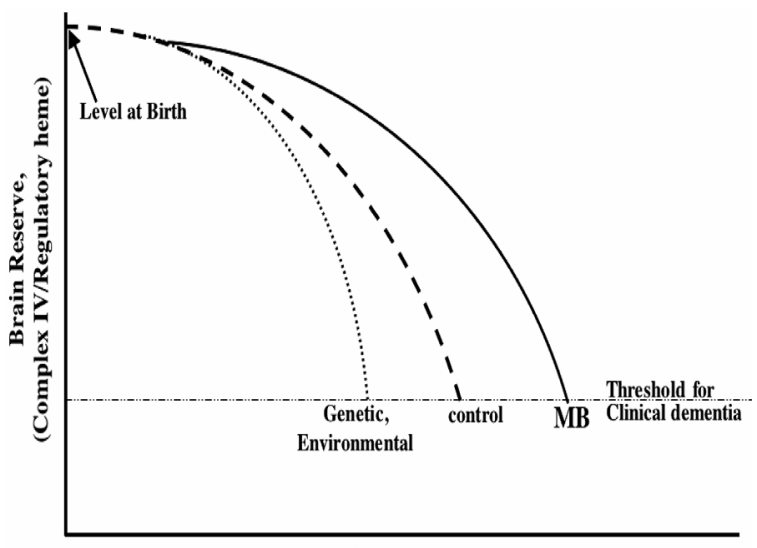

Age, Years

Fig. 1. The trajectory for the effect of MB on the age-dependent decline in complex IV or regulatory heme. This is hypothetical scheme presenting the trajectory with age (X-axis) for brain reserve at birth (Y-axis) of complex IV (or heme). Brain reserve declines with age until it reaches a critical threshold after which clinical signs become evident. We anticipate that MB may increase the brain reserve of complex IV and heme, thus extending the time to clinical threshold leading to a delay in the onset of clinical dementia (in this case $\mathrm{AD}$ ). An extreme case is depicted when genetic mutation or exposure to environmental factor, which may accelerate the decline in complex IV and heme.

plexes of the mitochondria [117], which may indicate the physiological significance of excess complex IV. However, there is no definitive answer as yet to the physiologic significance of the excess in complex IV, though minor decline in complex IV leads to disorders of energy metabolism and mitochondrial dysfunction. A decrease in complex IV activity causes cytotoxicity, leads to specific pathologies [118], increases oxidants production, and decreases the energy charge of the mitochondria $[119,120]$. On the other hand, the effect of an increase in complex IV on oxidants formation and energy metabolism is not known. Based on our in vitro and in vivo results, we anticipate that elevated levels of complex IV would improve mitochondrial function.

Energy production by mitochondria relies on four electron transport complexes (also known as the electron transport chain, ETC), which are complex I, II, III, and IV. Electron transfer through each one of the complexes starts at complex I, which catalyzes a twoelectron oxidation of $\mathrm{NADH}$, and continues until complex IV forms water. Complex IV consumes more than $95 \%$ of the $\mathrm{O}_{2}$ that reaches the cell. The production of $\mathrm{H}_{2} \mathrm{O}_{2}$ and other oxidants appears to be enhanced by the stalling of electrons upstream of complex IV (at complexes I and III) [32,121-123]. Complexes I and III are two sites responsible for the production of free radicals by non-specific transfer of electron to $\mathrm{O}_{2}$. Thus, excess complex IV may play a key role in decreasing the steady-state concentration of intracellular $\mathrm{O}_{2}$ and, as a result, lowering the production of oxidants by the mitochondria. Furthermore, a high level of complex IV correlates with the metabolic activity of the cell and with cognitive performance.

A decline in $\mathrm{H}_{2} \mathrm{O}_{2}$ production upon induction of complex IV limits the catalytic activity of huA $\beta$-heme perxidase [48], which requires $\mathrm{H}_{2} \mathrm{O}_{2}$ as a co-substrate. Furthermore, enhancing heme synthesis should provide neural cells with better reserve and capacity to provide regulatory heme, thus delaying the onset of the consequences of sequestration of heme by huA $\beta$. These effects of $\mathrm{MB}$ on cell metabolism and mitochondrial complex IV in particular suggest that MB may delay the onset of AD (Fig. 1).

Aggregation of $\mathrm{p}$-tau has been prevented at $\approx 3 \mu \mathrm{M}$ $\mathrm{MB}$ in test tube [124]. Furthermore, MB at a concentration higher than $15 \mu \mathrm{M}$ has been shown to inhibit $\mathrm{A} \beta$ oligomerization by promoting fibrillization [125]. The concentration of MB used are very high and may lead to neurotoxicity $[114,126]$. MB exhibits cellular toxicity at $\mu \mathrm{M}$ range of concentration and may harm the nerve cells. Our findings show that MB is effective at improving mitochondrial function at $\mathrm{nM}$ range of concentrations, which is consistent with the intra brain concentration that can be achieved upon chronic treatment with MB [115].

MB has a promising potential to delay the onset of AD [114,127] since it also has the added benefit of being known for human use; it has a very long-standing, extensive history of medical uses [128]. Thus, MB is a drug with an extended medical and safety record in humans, and FDA approval for its testing in clinical trials in connotation to aging and age-related disorders may not be denied on safety grounds.

\section{PROPERTIES OF METHYLENE BLUE}

Methylene blue (3,7 Bis-dimethylamino-phenazathionium) is known as a redox indicator with a redox potential of $11 \mathrm{mV}$. The low redox potential allows MB to cycle readily between oxidized and reduced forms by various redox centers such as those present in mitochondria (Scheme 1). Several NAD(P)H-dependent dehydrogenases also reduce $\mathrm{MB}$ to form the colorless leucomethylene blue $\left(\mathrm{MBH}_{2}\right) . \mathrm{MBH}_{2}$ can be reoxidized to $\mathrm{MB}$ by $\mathrm{O}_{2}$ in the absence of suitable electron acceptors such as cytochrome $c$ [129] or other hemeproteins [130]. 


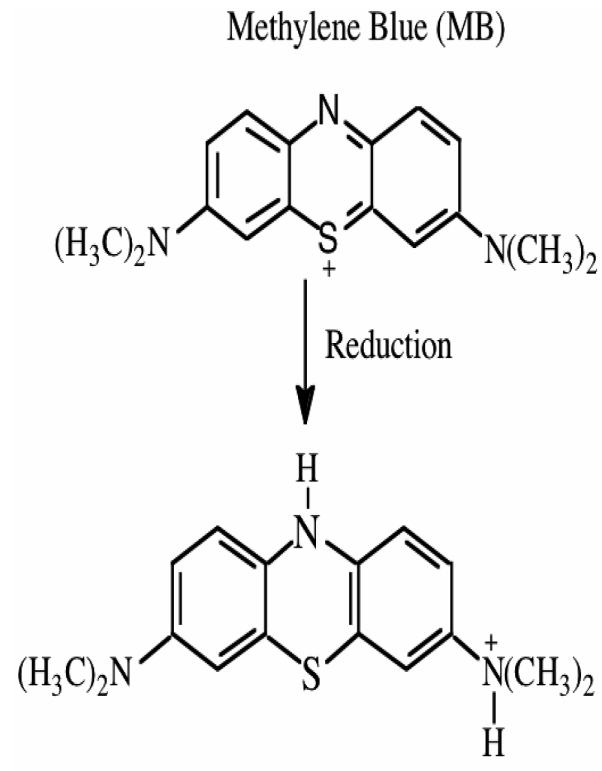

Leucomethylene Blue (colorless)

Scheme 1: The oxidized and reduced structures of methylene blue.

$\mathrm{MB}$ is soluble in both water and organic solvents; the lipid solubility of $\mathrm{MBH}_{2}$ is higher than that of MB. Electron delocalization in MB results in a partial positive charge being located on both nitrogen and sulfur atoms, which may increase the permeability of MB through membranes. Thus, $\mathrm{MBH}_{2}$ and $\mathrm{MB}$ can enter the mitochondria and other intracellular compartments such as lysosomes [131].

When exposed to high intensity of UV light, MB causes oxidative damage to isolated DNA. No such toxicity has been shown in humans [132], presumably because it requires high exposure to UV and most MB in vivo is in the reduced form of $\mathrm{MBH}_{2}$, which does not have photodynamic activity [133].

\section{Clinical uses of methylene blue}

MB has been in clinical use for decades to treat a variety of pathological conditions and diseases. MB is readily absorbed and quickly distributed to various organs including the brain [134]. One of the most common uses of MB is the chronic treatment of congenital methemoglobinemia, which is due to methemoglobin reductase deficiency. $\mathrm{MB}$ is also used to treat methemoglobinemia caused by cyanide, $\mathrm{CO}$, or nitrate poisoning [135]. Recent clinical uses for MB include preventing the side effects of chemotherapy (e.g., ifosfamide-induced encaphelopathy [136]) and preventing hypotension in septic shock [137]. MB is

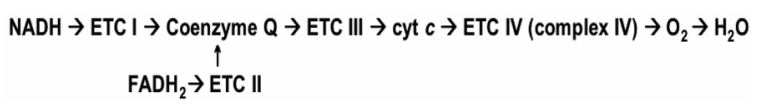

Scheme 2: The electron transport chain (ETC) of the mitochondria. The four complexes are: complex I (ETC I), complex II (ETC II), complex III (ETC III), and complex IV (ETC IV) in addition to ATP synthase (i.e., complex V). The electron transfer through each one of the ETC starts at ETC I, which catalyzes two electrons oxidation of NADH and continues until water is formed on ETC IV. Coenzyme Q serves as low molecular weight electron carrier from ETCs I and II to III. Cytochrome $c$ (cyt $c$ ) serves as electron carrier from ETC III to ETC IV.

also used in the treatment of some psychiatric disorders because of its anxiolytic and antidepressant properties $[138,139]$. The typical dose of MB in clinical uses ranges between 1-2 mg/kg/day; however, MB can also be repeatedly administered at this dose up to 6 times over $24 \mathrm{~h}$ [135]. High non-therapeutic doses ( $>$ $7.5 \mathrm{mg} / \mathrm{Kg}$ ) of MB cause the formation of Heinz bodies in erythrocytes in humans [140] and impairs hematological parameters in rodents [141].

Research into additional medical uses of $\mathrm{MB}$ is in progress. MB has been shown to protect against cyclosporine injury to the kidney [142] and streptozotocin injury to the pancreas [143]. MB also protects from ischemic-reperfusion injury [144], radiation [145], and enhances $\beta$-oxidation of long chain fatty acids [146].

Administering $\mathrm{MB}$ in vivo benefits the central nervous system: MB improves the cognitive function in rats and increased the activity of cytochrome $c$ oxidase (complex IV) in the brain by $25 \%$ (after single high dose) $[147,148]$. Previous findings show that MB inhibits the activity of monoamine oxidase in the brain, which may lead to an increase in the concentration of dopamine [149].

\section{Proposed mechanisms of actions of methylene blue in current clinical applications}

The mechanism(s) of the diverse biological actions of MB described above are not clear. MB has been proposed to act by inhibiting the NO-activating soluble guanylate cyclase (sGC) [150] (though the basal activity of sGC is not affected); inhibiting nitric oxide synthase (NOS) [126]; inhibiting MAO [149]; and acting as an antioxidant precursor $[130,151]$. The effects of $\mathrm{MB}$ were measured at concentrations greater than $10 \mu \mathrm{M}$. However, recent studies showed the effects of MB are inconsistent with the above proposed mechanisms [114,152]. These discrepancies may be because MB exhibits different effects at different concentrations ( $>10 \mu \mathrm{M}$ versus $<1 \mu \mathrm{M}$ ). Thus, these mechanisms 


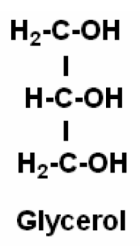

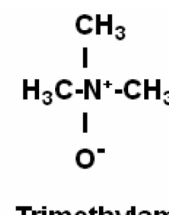

TrimethylamineN-oxide

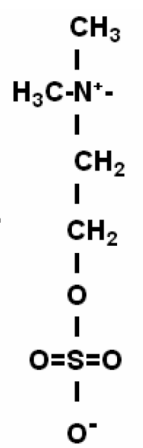

$0^{-}$
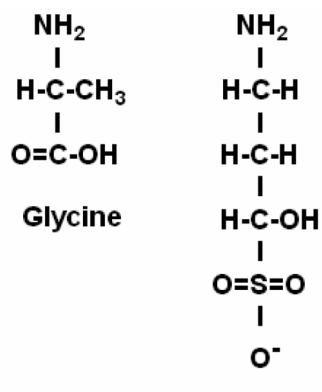

Taurine

\section{Choline-O-sulphate}

Scheme 3: Examples of some well-known osmolytes.

may explain some, but not all of the biological actions of $\mathrm{MB}$, we observed when using $\mathrm{MB}$ at $\mathrm{nM}$ concentrations [114].

Using our experimental findings in conjunction with previous studies on MB, we proposed for the first time a molecular mechanism explaining, in part, the effect of MB on mitochondria [114]. Briefly, MB can readily cycle between the oxidized $(\mathrm{MB})$ and the reduced $\left(\mathrm{MBH}_{2}\right)$ forms [153]. NAD $(\mathrm{P}) \mathrm{H}$-dependent dehydrogenases (e.g., NADH-dehydrogenase of complex I) can reduce artificial electron acceptors such as $\mathrm{MB}$ to $\mathrm{MBH}_{2}$ or $\mathrm{O}_{2}$ to superoxide radical [122]. Thus, we proposed that $\mathrm{MBH}_{2}$ and $\mathrm{MB}$ serve as electron carriers between several dehydrogenases and heme-proteins (e.g., cytochrome $c$ ). In turn, complex IV recycles the reduced cytochrome $c$ (Scheme 2). If this cycling of MB occurs within the mitochondrial ETC, we predicted an inhibition of the production of superoxide radical by $\mathrm{MB}$ by competing with $\mathrm{O}_{2}$ at the site of free radical production at NADH-dehydrogenase of complex I [122]. NADH-dehydrogenase of complex I faces the matrix, thus part of the $\mathrm{MBH}_{2}$ will be formed in the mitochondrial matrix in addition to the cytosol. The hydrophobicity of $\mathrm{MBH}_{2}$ increases upon reduction, thus increasing the chances that $\mathrm{MBH}_{2}$ crosses the mitochondrial inner membrane and reaches cytochrome $c$ and complex IV. This mechanism has previously been explained in more detail [114].

Intracellular MB is likely to cycle between the oxidized $(\mathrm{MB})$ and the reduced $\left(\mathrm{MBH}_{2}\right)$ forms. Although numerous $\mathrm{NAD}(\mathrm{P}) \mathrm{H}$-dependent enzymes can reduce $\mathrm{MB}$ to $\mathrm{MBH}_{2}$, cytochrome $c$ in the mitochondria and methemoglobin (in the red blood cells) are the only heme proteins reported to reoxidize $\mathrm{MBH}_{2}$ to $\mathrm{MB}$ [129, 130]. Cytochrome $c$ is an electron carrier from complex III (the natural enzyme that reduces cytochrome c) to complex IV (the natural enzyme that oxidizes cytochrome $c$ ). Thus, $\mathrm{MBH}_{2}$ may increase the rate of the reduction of cytochrome $c$ over and above the normal enzymatic reduction by complex III. Complex IV catalyzes the electron transfer from the reduced cytochrome $c$ to $\mathrm{O}_{2}$ to form $\mathrm{H}_{2} \mathrm{O}$. Increased reduction of cytochrome $c$ by $\mathrm{MBH}_{2}[129,130]$ could explain, in part, the increase in complex IV that occurs in the presence of $100 \mathrm{nM}$ MB [114]. Cycling of MB between oxidized and reduced forms may block oxidant production by mitochondria. Mitochondrial dysfunction and oxidative stress are thought to be key aberrations that lead to cellular senescence, aging, and AD.

Adequate assembly and activity of complex IV depends on heme- $a$ [154], which exists only in complex IV. Thus, the increase in the level of complex IV requires an increase in heme, which is the precursor for heme- $a$. The increase in the rate in heme synthesis we observed at $100 \mathrm{nM} \mathrm{MB}$, could provide cells with the heme- $a$ to support the assembly of complex IV.

Complexes I and III of the mitochondria, which are upstream to complex IV, are implicated in the production of free radicals by non-specific transfer of electrons to $\mathrm{O}_{2}$. Thus, stalling electrons at ETCs upstream of complex IV enhances production of oxygen free radicals. Close to $95 \%$ of the intracellular $\mathrm{O}_{2}$ is consumed by complex IV. Consistent with the increase in complex IV by $\mathrm{MB}$, we found an increase in $\mathrm{O}_{2}$ consumption in cells maintained in $100 \mathrm{nM}$ MB. Thus, possible advantages of high level of complex IV is minimizing "electrons dwelling" at complexes I and III and increasing the conversion of the $\mathrm{O}_{2}$ to water. Both effects of complex IV act to decrease oxidant production (e.g., $\mathrm{H}_{2} \mathrm{O}_{2}$ ) [32]. Thus, elevated complex IV induced by MB may lower the oxidative stress and oxidative damage. High levels of complex IV also increase mitochondrial activity, which would improve energy status. 


\section{SUMMARY}

We proposed two different approaches to prevent or delay the onset of AD. The first is directed at enhancing mitochondrial activity using $\mathrm{MB}$ to increase the level of complex IV (Fig. 1). Successful merger of treatment with $\mathrm{MB}$ and intranasal delivery of insulin to the brain [68] may prove valuable for AD patients. Energy deficiency in AD may be contributed by impaired insulin (glucose) metabolism and mitochondrial function. Thus, concentrating on single impairment at the time would not be enough to resolve the energy hypometabolism in AD. Glucose metabolism depends on adequately functioning mitochondria and vice versa. Since both glucose and mitochondrial metabolism are interconnected, it might be more beneficial for AD patients to develop a therapeutic approach that resolves (or delays) both impairments. MB exerts its effect at very low (nM) concentration, which in conjunction with its safety record in humans, further minimizes any risk of side effects of chronic exposure to MB. The second approach is directed at preventing the aggregation of $\mathrm{A} \beta$ by using osmolytes, natural metabolites synthesized in the brain. Preventing the aggregation of $\mathrm{A} \beta$ may enhance their proteolytic removal and decrease the risk of their interference with heme and mitochondrial metabolism. MB can also induce heme synthesis, thus, when combined with osmolytes, may assist in preventing heme deficiency. We propose MB and osmolytes could help delay the onset of AD by preventing $\mathrm{A} \beta$ oligomers formation, enhancing mitochondrial function, and attenuating heme deficiency.

\section{ACKNOWLEDGMENTS}

Study was supported in part by Ames foundation and AFAR (HA) and NIH (RK). We are grateful for Prof. William H. Frey II, Jennifer Cawley, and Doaa Atamna for reading the manuscript.

Authors' disclosures available online (http://www.jalz.com/disclosures/view.php?id=415).

\section{REFERENCES}

[1] Haass C, Selkoe DJ (2007) Soluble protein oligomers in neurodegeneration: lessons from the Alzheimer's amyloid beta-peptide. Nat Rev Mol Cell Biol 8, 101-112.

[2] Nunan J, Small DH (2000) Regulation of APP cleavage by alpha-, beta- and gamma-secretases. FEBS Lett 483, 6-10.
[3] Blasko I, Beer R, Bigl M, Apelt J, Franz G, Rudzki D, Ransmayr G, Kampfl A, Schliebs R (2004) Experimental traumatic brain injury in rats stimulates the expression, production and activity of Alzheimer's disease beta-secretase (BACE-1). J Neural Transm 111, 523-536.

[4] Farrer LA, Cupples LA, Haines JL, Hyman B, Kukull WA, Mayeux R, Myers RH, Pericak-Vance MA, Risch N, van Duijn CM (1997) Effects of age, sex, and ethnicity on the association between apolipoprotein E genotype and Alzheimer disease. A meta-analysis. APOE and Alzheimer Disease Meta Analysis Consortium. JAMA 278, 1349-1356.

[5] Landrigan PJ, Sonawane B, Butler RN, Trasande L, Callan R, Droller D (2005) Early environmental origins of neurodegenerative disease in later life. Environ Health Perspect 113, 1230-1233.

[6] Prasad GS, Wahlberg M, Sridhar V, Sundaresan V, Yamaguchi M, Hatefi Y, Stout CD (2002) Crystal structures of transhydrogenase domain I with and without bound NADH. Biochemistry 41, 12745-12754.

[7] Atwood CS, Martins RN, Smith MA, Perry G (2002) Senile plaque composition and posttranslational modification of amyloid-beta peptide and associated proteins. Peptides $\mathbf{2 3}$, 1343-1350.

[8] Atamna H (2006) Heme binding to Amyloid-beta peptide: Mechanistic role in Alzheimer's disease. J Alzheimers Dis 10, 255-266.

[9] Castellani RJ, Lee HG, Siedlak SL, Nunomura A, Hayashi T, Nakamura M, Zhu X, Perry G, Smith MA (2009) Reexamining Alzheimer's disease: evidence for a protective role for amyloid-beta protein precursor and amyloid-beta. $J$ Alzheimers Dis 18, 447-452.

[10] Reddy PH, Beal MF (2008) Amyloid beta, mitochondrial dysfunction and synaptic damage: implications for cognitive decline in aging and Alzheimer's disease. Trends Mol Med 14, 45-53.

[11] Manczak M, Anekonda TS, Henson E, Park BS, Quinn J, Reddy PH (2006) Mitochondria are a direct site of A beta accumulation in Alzheimer's disease neurons: implications for free radical generation and oxidative damage in disease progression. Hum Mol Genet 15, 1437-1449.

[12] Reddy PH (2009) Amyloid beta, mitochondrial structural and functional dynamics in Alzheimer's disease. Exp Neurol 218 , 286-292.

[13] Hartmann T, Bieger SC, Bruhl B, Tienari PJ, Ida N, Allsop D, Roberts GW, Masters CL, Dotti CG, Unsicker K, Beyreuther K (1997) Distinct sites of intracellular production for Alzheimer's disease A beta40/42 amyloid peptides. Nat Med 3, 1016-1020.

[14] Fezoui Y, Hartley DM, Harper JD, Khurana R, Walsh DM, Condron MM, Selkoe DJ, Lansbury PT, Jr., Fink AL, Teplow DB (2000) An improved method of preparing the amyloid beta-protein for fibrillogenesis and neurotoxicity experiments. Amyloid 7, 166-178.

[15] Mucke L, Masliah E, Yu GQ, Mallory M, Rockenstein EM, Tatsuno G, Hu K, Kholodenko D, Johnson-Wood K, McConlogue L (2000) High-level neuronal expression of abeta 1-42 in wild-type human amyloid protein precursor transgenic mice: synaptotoxicity without plaque formation. $J$ Neurosci 20, 4050-4058.

[16] Kern A, Behl C (2009) The unsolved relationship of brain aging and late-onset Alzheimer disease. Biochim Biophys Acta 1790, 1124-1132.

[17] Bierer LM, Hof PR, Purohit DP, Carlin L, Schmeidler J, Davis KL, Perl DP (1995) Neocortical neurofibrillary tangles 
correlate with dementia severity in Alzheimer's disease. Arch Neurol 52, 81-88.

[18] Aliev G, Seyidova D, Lamb BT, Obrenovich ME, Siedlak SL, Vinters HV, Friedland RP, LaManna JC, Smith MA, Perry G (2003) Mitochondria and vascular lesions as a central target for the development of Alzheimer's disease and Alzheimer disease-like pathology in transgenic mice. Neurol Res $\mathbf{2 5}$, 665-674.

[19] Gong Y, Chang L, Viola KL, Lacor PN, Lambert MP, Finch CE, Krafft GA, Klein WL (2003) Alzheimer's diseaseaffected brain: presence of oligomeric A beta ligands (ADDLs) suggests a molecular basis for reversible memory loss. Proc Natl Acad Sci U S A 100, 10417-10422.

[20] Devi L, Prabhu BM, Galati DF, Avadhani NG, Anandatheerthavarada HK (2006) Accumulation of amyloid precursor protein in the mitochondrial import channels of human Alzheimer's disease brain is associated with mitochondrial dysfunction. J Neurosci 26, 9057-9068.

[21] Baloyannis SJ (2006) Mitochondrial alterations in Alzheimer's disease. J Alzheimers Dis 9, 119-126.

[22] Golde TE, Janus C (2005) Homing in on intracellular Abeta? Neuron 45, 639-642.

[23] Freir DB, Fedriani R, Scully D, Smith IM, Selkoe DJ, Walsh DM, Regan CM (2010) Abeta oligomers inhibit synapse remodelling necessary for memory consolidation. Neurobiol Aging, in press.

[24] Walsh DM, Klyubin I, Fadeeva JV, Cullen WK, Anwyl R, Wolfe MS, Rowan MJ, Selkoe DJ (2002) Naturally secreted oligomers of amyloid beta protein potently inhibit hippocampal long-term potentiation in vivo. Nature 416, 535-539.

[25] Lambert MP, Barlow AK, Chromy BA, Edwards C, Freed R, Liosatos M, Morgan TE, Rozovsky I, Trommer B, Viola KL, Wals P, Zhang C, Finch CE, Krafft GA, Klein WL (1998) Diffusible, nonfibrillar ligands derived from Abeta1-42 are potent central nervous system neurotoxins. Proc Natl Acad Sci U S A 95, 6448-6453.

[26] Atamna H (2009) Amino acids variations in Amyloid-beta peptides, mitochondrial dysfunction, and new therapies for Alzheimer's disease. J Bioenerg Biomembr 41, 457-464.

[27] Parker WD, Jr., Filley CM, Parks JK (1990) Cytochrome oxidase deficiency in Alzheimer's disease. Neurology 40, 1302-1303.

[28] Valla J, Berndt JD, Gonzalez-Lima F (2001) Energy hypometabolism in posterior cingulate cortex of Alzheimer's patients: superficial laminar cytochrome oxidase associated with disease duration. J Neurosci 21, 4923-4930.

[29] Daly C, Sugimori M, Moreira JE, Ziff EB, Llinas R (2000) Synaptophysin regulates clathrin-independent endocytosis of synaptic vesicles. Proc Natl Acad Sci U S A 97, 6120-6125.

[30] Markesbery WR (1997) Oxidative stress hypothesis in Alzheimer's disease. Free Radic Biol Med 23, 134-147.

[31] Connor JR, Menzies SL, St Martin SM, Mufson EJ (1992) A histochemical study of iron, transferrin, and ferritin in Alzheimer's diseased brains. J Neurosci Res 31, 75-83.

[32] Fu M, Zhu X, Zhang J, Liang J, Lin Y, Zhao L, Ehrengruber MU, Chen YE (2003) Egr-1 target genes in human endothelial cells identified by microarray analysis. Gene $\mathbf{3 1 5}$, 33-41.

[33] Sohal RS (1993) Aging, cytochrome oxidase activity, and hydrogen peroxide release by mitochondria. Free Radic Biol Med 14, 583-588.

[34] Boveris A, Chance B (1973) The mitochondrial generation of hydrogen peroxide. General properties and effect of hyperbaric oxygen. Biochem $J$ 134, 707-716.
[35] Atamna H (2004) Heme, iron, and the mitochondrial decay of ageing. Ageing Res Rev 3, 303-318.

[36] Atamna H, Killilea DW, Killilea AN, Ames BN (2002) Heme deficiency may be a factor in the mitochondrial and neuronal decay of aging. Proc Natl Acad Sci U S A 99, 14807-14812.

[37] Lustbader JW, Cirilli M, Lin C, Xu HW, Takuma K, Wang N, Caspersen C, Chen X, Pollak S, Chaney M, Trinchese F, Liu S, Gunn-Moore F, Lue LF, Walker DG, Kuppusamy P, Zewier ZL, Arancio O, Stern D, Yan SS, Wu H (2004) ABAD directly links Abeta to mitochondrial toxicity in Alzheimer's disease. Science 304, 448-452.

[38] Yamaguchi H, Yamazaki T, Ishiguro K, Shoji M, Nakazato Y, Hirai S (1992) Ultrastructural localization of Alzheimer amyloid beta/A4 protein precursor in the cytoplasm of neurons and senile plaque-associated astrocytes. Acta Neuropathol (Berl) 85, 15-22.

[39] Crouch PJ, Blake R, Duce JA, Ciccotosto GD, Li QX, Barnham KJ, Curtain CC, Cherny RA, Cappai R, Dyrks T, Masters CL, Trounce IA (2005) Copper-dependent inhibition of human cytochrome c oxidase by a dimeric conformer of amyloid-beta1-42. J Neurosci 25, 672-679.

[40] Cho DH, Nakamura T, Fang J, Cieplak P, Godzik A, Gu Z, Lipton SA (2009) S-nitrosylation of Drp1 mediates betaamyloid-related mitochondrial fission and neuronal injury. Science 324, 102-105.

[41] Wang X, Su B, Siedlak SL, Moreira PI, Fujioka H, Wang Y, Casadesus G, Zhu X (2008) Amyloid-beta overproduction causes abnormal mitochondrial dynamics via differential modulation of mitochondrial fission/fusion proteins. Proc Natl Acad Sci U S A 105, 19318-19323.

[42] Du H, Guo L, Fang F, Chen D, Sosunov AA, McKhann GM, Yan Y, Wang C, Zhang H, Molkentin JD, Gunn-Moore FJ, Vonsattel JP, Arancio O, Chen JX, Yan SD (2008) Cyclophilin $\mathrm{D}$ deficiency attenuates mitochondrial and neuronal perturbation and ameliorates learning and memory in Alzheimer's disease. Nat Med 14, 1097-1105.

[43] Mutisya EM, Bowling AC, Beal MF (1994) Cortical cytochrome oxidase activity is reduced in Alzheimer's disease. J Neurochem 63, 2179-2184.

[44] Parker WD, Jr., Mahr NJ, Filley CM, Parks JK, Hughes D, Young DA, Cullum CM (1994) Reduced platelet cytochrome c oxidase activity in Alzheimer's disease. Neurology 44, 1086-1090.

[45] Blass JP, Sheu RK, Gibson GE (2000) Inherent abnormalities in energy metabolism in Alzheimer disease. Interaction with cerebrovascular compromise. Ann N Y Acad Sci 903, 204221.

[46] Bubber P, Haroutunian V, Fisch G, Blass JP, Gibson GE (2005) Mitochondrial abnormalities in Alzheimer brain: mechanistic implications. Ann Neurol 57, 695-703.

[47] Furuyama K, Sassa S (2000) Interaction between succinyl CoA synthetase and the heme-biosynthetic enzyme ALAS-E is disrupted in sideroblastic anemia. J Clin Invest 105, 757764.

[48] Atamna H, Frey WH, 2nd (2007) Mechanisms of mitochondrial dysfunction and energy deficiency in Alzheimer's disease. Mitochondrion 7, 297-310.

[49] Su B, Wang X, Bonda D, Perry G, Smith M, Zhu X (2010) Abnormal mitochondrial dynamics-a novel therapeutic target for Alzheimer's disease? Mol Neurobiol 41, 87-96.

[50] Lovell MA, Robertson JD, Teesdale WJ, Campbell JL, Markesbery WR (1998) Copper, iron and zinc in Alzheimer's disease senile plaques. J Neurol Sci 158, 47-52. 
[51] Avdulov NA, Chochina SV, Igbavboa U, Warden CS, Vassiliev AV, Wood WG (1997) Lipid binding to amyloid betapeptide aggregates: preferential binding of cholesterol as compared with phosphatidylcholine and fatty acids. $\mathrm{J} \mathrm{Neu}$ rochem 69, 1746-1752.

[52] Bartzokis G, Tishler TA, Lu PH, Villablanca P, Altshuler LL, Carter M, Huang D, Edwards N, Mintz J (2007) Brain ferritin iron may influence age- and gender-related risks of neurodegeneration. Neurobiol Aging 28, 414-423.

[53] Cullen KM, Kocsi Z, Stone J (2006) Microvascular pathology in the aging human brain: evidence that senile plaques are sites of microhaemorrhages. Neurobiol Aging 27, 1786-1796.

[54] Gatta LB, Vitali M, Verardi R, Arosio P, Finazzi D (2009) Inhibition of heme synthesis alters Amyloid Precursor Protein processing. J Neural Transm 116, 79-88.

[55] Perry RT, Gearhart DA, Wiener HW, Harrell LE, Barton JC, Kutlar A, Kutlar F, Ozcan O, Go RC, Hill WD (2008) Hemoglobin binding to A beta and HBG2 SNP association suggest a role in Alzheimer's disease. Neurobiol Aging 29, 185-193.

[56] Fukuyama K, Kunishima N, Amada F, Kubota T, Matsubara $\mathrm{H}$ (1995) Crystal structures of cyanide- and triiodide-bound forms of Arthromyces ramosus peroxidase at different $\mathrm{pH}$ values. Perturbations of active site residues and their implication in enzyme catalysis. J Biol Chem 270, 21884-21892.

[57] Paoli M, Marles-Wright J, Smith A (2002) Structure-function relationships in heme-proteins. DNA Cell Biol 21, 271-280.

[58] Rojas NR, Kamtekar S, Simons CT, McLean JE, Vogel KM, Spiro TG, Farid RS, Hecht MH(1997) De novo heme proteins from designed combinatorial libraries. Protein Sci 6, 25122524.

[59] Sassa S (2004) Why heme needs to be degraded to iron, biliverdin IXalpha, and carbon monoxide? Antioxid Redox Signal 6, 819-824.

[60] Faller M, Matsunaga M, Yin S, Loo JA, Guo F (2007) Heme is involved in microRNA processing. Nat Struct Mol Biol 14, 23-29.

[61] Sassa S (2007) [Gene regulation by free heme]. Nippon Yakurigaku Zasshi 130, 248-251.

[62] Kelley BJ, Knopman DS (2008) Alternative medicine and Alzheimer disease. Neurologist 14, 299-306.

[63] Bellinger DC, Trachtenberg F, Barregard L, Tavares M, Cernichiari E, Daniel D, McKinlay S (2006) Neuropsychological and renal effects of dental amalgam in children: a randomized clinical trial. JAMA 295, 1775-1783.

[64] Beal MF (2005) Oxidative damage as an early marker of Alzheimer's disease and mild cognitive impairment. Neurobiol Aging 26, 585-586.

[65] Butterfield DA (2002) Amyloid beta-peptide (1-42)-induced oxidative stress and neurotoxicity: implications for neurodegeneration in Alzheimer's disease brain. A review. Free Radic Res 36, 1307-1313.

[66] Hirai K, Aliev G, Nunomura A, Fujioka H, Russell RL, Atwood CS, Johnson AB, Kress Y, Vinters HV, Tabaton M, Shimohama S, Cash AD, Siedlak SL, Harris PL, Jones PK, Petersen RB, Perry G, Smith MA (2001) Mitochondrial abnormalities in Alzheimer's disease. J Neurosci 21, 3017-3023.

[67] Beal MF (2000) Energetics in the pathogenesis of neurodegenerative diseases. Trends Neurosci 23, 298-304.

[68] Dhuria SV, Hanson LR, Frey WH, 2nd (2010) Intranasal delivery to the central nervous system: mechanisms and experimental considerations. J Pharm Sci 99, 1654-1673.

[69] Reger MA, Watson GS, Green PS, Baker LD, Cholerton B, Fishel MA, Plymate SR, Cherrier MM, Schellenberg GD,
Frey WH, 2nd, Craft S (2008) Intranasal insulin administration dose-dependently modulates verbal memory and plasma amyloid-beta in memory-impaired older adults. J Alzheimers Dis 13, 323-331.

[70] Luo GR, Le WD (2010) Collective roles of molecular chaperones in protein degradation pathways associated with neurodegenerative diseases. Curr Pharm Biotechnol 11, 180187.

[71] Hochachka PW, Somero GN (2002) Biochemical Adaptation. Mechanism and Process in Physiological Evolution, Oxford University Press, Oxford, UK.

[72] Bolen DW, Baskakov IV (2001) The osmophobic effect: natural selection of a thermodynamic force in protein folding. $J$ Mol Biol 310, 955-963.

[73] Baldwin RL, Rose GD (1999) Is protein folding hierarchic? I. Local structure and peptide folding. Trends Biochem Sci 24, 26-33.

[74] Burg MB (1995) Molecular basis of osmotic regulation. Am J Physiol 268, F983-996.

[75] Bai C, Biwersi J, Verkman AS, Matthay MA (1998) A mouse model to test the in vivo efficacy of chemical chaperones. $J$ Pharmacol Toxicol Methods 40, 39-45.

[76] Pace CN (1975) The stability of globular proteins. CRC Crit Rev Biochem 3, 1-43.

[77] Yancey PH, Clark ME, Hand SC, Bowlus RD, Somero GN (1982) Living with water stress: evolution of osmolyte systems. Science 217, 1214-1222.

[78] Atamna H, Ginsburg H (1995) Heme degradation in the presence of glutathione. A proposed mechanism to account for the high levels of non-heme iron found in the membranes of hemoglobinopathic red blood cells. J Biol Chem 270, 2487624883.

[79] Mello CC, Barrick D (2003) Measuring the stability of partly folded proteins using TMAO. Protein Sci 12, 1522-1529.

[80] Yancey PH (2005) Organic osmolytes as compatible, metabolic and counteracting cytoprotectants in high osmolarity and other stresses. J Exp Biol 208, 2819-2830.

[81] Baskakov I, Bolen DW (1998) Forcing thermodynamically unfolded proteins to fold. J Biol Chem 273, 4831-4834.

[82] Quinones QJ, de Ridder GG, Pizzo SV (2008) GRP78: a chaperone with diverse roles beyond the endoplasmic reticulum. Histol Histopathol 23, 1409-1416.

[83] Kelly JW (1998) The alternative conformations of amyloidogenic proteins and their multi-step assembly pathways. Curr Opin Struct Biol 8, 101-106.

[84] Lansbury PT, Jr. (1999) Evolution of amyloid: what normal protein folding may tell us about fibrillogenesis and disease. Proc Natl Acad Sci U S A 96, 3342-3344.

[85] Davies SW, Turmaine M, Cozens BA, DiFiglia M, Sharp AH, Ross CA, Scherzinger E, Wanker EE, Mangiarini L, Bates GP (1997) Formation of neuronal intranuclear inclusions underlies the neurological dysfunction in mice transgenic for the HD mutation. Cell 90, 537-548.

[86] Warrick JM, Paulson HL, Gray-Board GL, Bui QT, Fischbeck KH, Pittman RN, Bonini NM (1998) Expanded polyglutamine protein forms nuclear inclusions and causes neural degeneration in Drosophila. Cell 93, 939-949.

[87] Klement IA, Skinner PJ, Kaytor MD, Yi H, Hersch SM, Clark HB, Zoghbi HY, Orr HT (1998) Ataxin-1 nuclear localization and aggregation: role in polyglutamine-induced disease in SCA1 transgenic mice. Cell 95, 41-53.

[88] Strong TV, Tagle DA, Valdes JM, Elmer LW, Boehm K, Swaroop M, Kaatz KW, Collins FS, Albin RL (1993) Widespread 
expression of the human and rat Huntington's disease gene in brain and nonneural tissues. Nat Genet 5, 259-265.

[89] Kennedy WR, Alter M, Sung JH (1968) Progressive proximal spinal and bulbar muscular atrophy of late onset. A sex-linked recessive trait. Neurology 18, 671-680.

[90] La Spada AR, Wilson EM, Lubahn DB, Harding AE, Fischbeck KH (1991) Androgen receptor gene mutations in Xlinked spinal and bulbar muscular atrophy. Nature 352, 77 79.

[91] (1993) A novel gene containing a trinucleotide repeat that is expanded and unstable on Huntington's disease chromosomes. The Huntington's Disease Collaborative Research Group. Cell 72, 971-983.

[92] DiFiglia M, Sapp E, Chase KO, Davies SW, Bates GP, Vonsattel JP, Aronin N (1997) Aggregation of huntingtin in neuronal intranuclear inclusions and dystrophic neurites in brain. Science 277, 1990-1993.

[93] Kumar R (2009) Role of naturally occurring osmolytes in protein folding and stability. Arch Biochem Biophys 491, 1-6.

[94] Kempf B, Bremer E (1998) Uptake and synthesis of compatible solutes as microbial stress responses to high-osmolality environments. Arch Microbiol 170, 319-330.

[95] Lin TY, Timasheff SN (1994) Why do some organisms use a urea-methylamine mixture as osmolyte? Thermodynamic compensation of urea and trimethylamine $\mathrm{N}$-oxide interactions with protein. Biochemistry 33, 12695-12701.

[96] Singh R, Haque I, Ahmad F (2005) Counteracting osmolyte trimethylamine $\mathrm{N}$-oxide destabilizes proteins at $\mathrm{pH}$ below its pKa. Measurements of thermodynamic parameters of proteins in the presence and absence of trimethylamine $\mathrm{N}$-oxide. $J$ Biol Chem 280, 11035-11042.

[97] Anjum F, Rishi V, Ahmad F (2000) Compatibility of osmolytes with Gibbs energy of stabilization of proteins. Biochim Biophys Acta 1476, 75-84.

[98] Tanaka M, Machida Y, Niu S, Ikeda T, Jana NR, Doi H, Kurosawa M, Nekooki M, Nukina N (2004) Trehalose alleviates polyglutamine-mediated pathology in a mouse model of Huntington disease. Nat Med 10, 148-154.

[99] Davies P, Watt K, Kelly SM, Clark C, Price NC, McEwan IJ (2008) Consequences of poly-glutamine repeat length for the conformation and folding of the androgen receptor aminoterminal domain. $J$ Mol Endocrinol 41, 301-314.

[100] Duff J, Davies P, Watt K, McEwan IJ (2006) Structural dynamics of the human androgen receptor: implications for prostate cancer and neurodegenerative disease. Biochem Soc Trans 34, 1098-1102.

[101] Irvine RA, Ma H, Yu MC, Ross RK, Stallcup MR, Coetzee GA (2000) Inhibition of p160-mediated coactivation with increasing androgen receptor polyglutamine length. Hum Mol Genet 9, 267-274.

[102] Richards AB, Krakowka S, Dexter LB, Schmid H, Wolterbeek AP, Waalkens-Berendsen DH, Shigoyuki A, Kurimoto M (2002) Trehalose: a review of properties, history of use and human tolerance, and results of multiple safety studies. Food Chem Toxicol 40, 871-898.

[103] Walsh DM, Klyubin I, Shankar GM, Townsend M, Fadeeva JV, Betts V, Podlisny MB, Cleary JP, Ashe KH, Rowan MJ, Selkoe DJ (2005) The role of cell-derived oligomers of Abeta in Alzheimer's disease and avenues for therapeutic intervention. Biochem Soc Trans 33, 1087-1090.

[104] Singer MA, Lindquist S (1998) Multiple effects of trehalose on protein folding in vitro and in vivo. Mol Cell 1, 639-648.

[105] Davies JE, Sarkar S, Rubinsztein DC (2006) Trehalose reduces aggregate formation and delays pathology in a trans- genic mouse model of oculopharyngeal muscular dystrophy. Hum Mol Genet 15, 23-31.

[106] Liu R, Barkhordarian H, Emadi S, Park CB, Sierks MR (2005) Trehalose differentially inhibits aggregation and neurotoxicity of beta-amyloid 40 and 42 . Neurobiol Dis 20, 7481 .

[107] Reddy VP, Garrett MR, Perry G, Smith MA (2005) Carnosine: a versatile antioxidant and antiglycating agent. Sci Aging Knowledge Environ 2005, pe12.

[108] Mozdzan M, Szemraj J, Rysz J, Nowak D (2005) Antioxidant properties of carnosine re-evaluated with oxidizing systems involving iron and copper ions. Basic Clin Pharmacol Toxicol 96, 352-360.

[109] Fonteh AN, Harrington RJ, Tsai A, Liao P, Harrington MG (2007) Free amino acid and dipeptide changes in the body fluids from Alzheimer's disease subjects. Amino Acids 32, 213-224.

[110] Qi W, Zhang A, Good TA, Fernandez EJ (2009) Two disaccharides and trimethylamine $\mathrm{N}$-oxide affect Abeta aggregation differently, but all attenuate oligomer-induced membrane permeability. Biochemistry 48, 8908-8919.

[111] Yang DS, Yip CM, Huang TH, Chakrabartty A, Fraser PE (1999) Manipulating the amyloid-beta aggregation pathway with chemical chaperones. J Biol Chem 274, 32970-32974.

[112] Wagner G (2006) Towards a life prolonging pill? Small molecules with anti-ageing properties. Curr Drug Targets 7 , 1531-1537.

[113] Miller RA, Harrison DE, Astle CM, Floyd RA, Flurkey K, Hensley KL, Javors MA, Leeuwenburgh C, Nelson JF, Ongini E, Nadon NL, Warner HR, Strong R (2007) An Aging Interventions Testing Program: study design and interim report. Aging Cell 6, 565-575.

[114] Atamna H, Nguyen A, Schultz C, Boyle K, Newberry J, Kato H, Ames BN (2008) Methylene blue delays cellular senescence and enhances key mitochondrial biochemical pathways. FASEB J 22, 703-712.

[115] Atamna H, Gharib A (2010) Methylene Blue Induces Mitochondrial Complex IV and Improves Cognitive Function and Grip Strength in Old Mice, Nova Science Publishers, in press.

[116] Peter C, Hongwan D, Kupfer A, Lauterburg BH (2000) Pharmacokinetics and organ distribution of intravenous and oral methylene blue. Eur J Clin Pharmacol 56, 247-250.

[117] Capaldi RA (1982) Arrangement of proteins in the mitochondrial inner membrane. Biochim Biophys Acta 694, 291-306.

[118] Shoubridge EA (2001) Cytochrome c oxidase deficiency. Am J Med Genet 106, 46-52.

[119] Kushnareva Y, Murphy AN, Andreyev A (2002) Complex I-mediated reactive oxygen species generation: modulation by cytochrome $\mathrm{c}$ and $\mathrm{NAD}(\mathrm{P})+$ oxidation-reduction state. Biochem J 368, 545-553.

[120] Barros MH, Bandy B, Tahara EB, Kowaltowski AJ (2004) Higher respiratory activity decreases mitochondrial reactive oxygen release and increases life span in Saccharomyces cerevisiae. J Biol Chem 279, 49883-49888.

[121] Aliev G, Seyidova D, Neal ML, Shi J, Lamb BT, Siedlak SL, Vinters HV, Head E, Perry G, Lamanna JC, Friedland RP, Cotman CW (2002) Atherosclerotic lesions and mitochondria DNA deletions in brain microvessels as a central target for the development of human AD and AD-like pathology in aged transgenic mice. Ann N Y Acad Sci 977, 45-64.

[122] Grivennikova VG, Vinogradov AD (2006) Generation of superoxide by the mitochondrial Complex I. Biochim Biophys Acta 1757, 553-561. 
[123] Aksenov MY, Aksenova MV, Butterfield DA, Geddes JW, Markesbery WR (2001) Protein oxidation in the brain in Alzheimer's disease. Neuroscience 103, 373-383.

[124] Wischik CM, Edwards PC, Lai RY, Roth M, Harrington CR (1996) Selective inhibition of Alzheimer disease-like tau aggregation by phenothiazines. Proc Natl Acad Sci U S A 93, 11213-11218.

[125] Necula M, Breydo L, Milton S, Kayed R, van der Veer WE Tone P, Glabe CG (2007) Methylene blue inhibits amyloid Abeta oligomerization by promoting fibrillization. Biochemistry 46, 8850-8860.

[126] Mayer B, Brunner F, Schmidt K (1993) Inhibition of nitric oxide synthesis by methylene blue. Biochem Pharmacol 45, 367-374.

[127] Oz M, Lorke DE, Petroianu GA (2009) Methylene blue and Alzheimer's disease. Biochem Pharmacol 78, 927-932.

[128] Moura

$\mathrm{JC}$,

Cordeiro N (2003) 3,7-bis(dialkylamino)phenothiazin-5-ium derivatives: biomedical applications and biological activity. Curr Drug Targets 4, 133-141.

[129] McCord JM, Fridovich I (1970) The utility of superoxide dismutase in studying free radical reactions. II. The mechanism of the mediation of cytochrome c reduction by a variety of electron carriers. J Biol Chem 245, 1374-1377.

[130] Kelner MJ, Bagnell R, Hale B, Alexander NM (1988) Methylene blue competes with paraquat for reduction by flavoenzymes resulting in decreased superoxide production in the presence of heme proteins. Arch Biochem Biophys 262, 422426.

[131] Mellish KJ, Cox RD, Vernon DI, Griffiths J, Brown SB (2002) In vitro photodynamic activity of a series of methylene blue analogues. Photochem Photobiol 75, 392-397.

[132] Wagner SJ, Cifone MA, Murli H, Dodd RY, Myhr B (1995) Mammalian genotoxicity assessment of methylene blue in plasma: implications for virus inactivation. Transfusion 35, 407-413.

[133] Gabrielli D, Belisle E, Severino D, Kowaltowski AJ, Baptista MS (2004) Binding, aggregation and photochemical properties of methylene blue in mitochondrial suspensions. Photochem Photobiol 79, 227-232.

[134] Rengelshausen J, Burhenne J, Frohlich M, Tayrouz Y, Singh SK, Riedel KD, Muller O, Hoppe-Tichy T, Haefeli WE, Mikus G, Walter-Sack I (2004) Pharmacokinetic interaction of chloroquine and methylene blue combination against malaria. Eur J Clin Pharmacol 60, 709-715.

[135] Clifton J, 2nd, Leikin JB (2003) Methylene blue. Am J Ther 10, 289-291.

[136] Patel PN (2006) Methylene blue for management of Ifosfamide-induced encephalopathy. Ann Pharmacother 40, 299-303.

[137] Betten DP, Vohra RB, Cook MD, Matteucci MJ, Clark RF (2006) Antidote use in the critically ill poisoned patient. $J$ Intensive Care Med 21, 255-277.

[138] Naylor GJ, Martin B, Hopwood SE, Watson Y (1986) A two-year double-blind crossover trial of the prophylactic effect of methylene blue in manic-depressive psychosis. Biol Psychiatry 21, 915-920.

[139] de-Oliveira RW, Guimaraes FS (1999) Anxiolytic effect of methylene blue microinjected into the dorsal periaqueductal gray matter. Braz J Med Biol Res 32, 1529-1532.

[140] Sills MR, Zinkham WH (1994) Methylene blue-induced Heinz body hemolytic anemia. Arch Pediatr Adolesc Med 148, 306-310.

[141] Hejtmancik MR, Ryan MJ, Toft JD, Persing RL, Kurtz PJ, Chhabra RS (2002) Hematological effects in F344 rats and B6C3F1 mice during the 13-week gavage toxicity study of methylene blue trihydrate. Toxicol Sci 65, 126-134.

[142] Rezzani R, Rodella L, Corsetti G, Bianchi R (2001) Does methylene blue protect the kidney tissues from damage induced by ciclosporin A treatment? Nephron 89, 329-336.

[143] Haluzik M, Nedvidkova J, Skrha J (1999) Treatment with the NO-synthase inhibitor, methylene blue, moderates the decrease in serum leptin concentration in streptozotocininduced diabetes. Endocr Res 25, 163-171.

[144] Salaris SC, Babbs CF, Voorhees WD, 3rd (1991) Methylene blue as an inhibitor of superoxide generation by xanthine oxidase. A potential new drug for the attenuation of ischemia/reperfusion injury. Biochem Pharmacol 42, 499-506.

[145] Teicher BA, Herman TS, Kaufmann ME (1990) Cytotoxicity, radiosensitization, and DNA interaction of platinum complexes of thiazin and xanthene dyes. Radiat Res 121, 187-195.

[146] Visarius TM, Stucki JW, Lauterburg BH (1999) Inhibition and stimulation of long-chain fatty acid oxidation by chloroacetaldehyde and methylene blue in rats. J Pharmacol Exp Ther 289, 820-824.

[147] Martinez JL, Jensen RA, Vasquez Bj, Mcguinness T, Mcgaugh Jl (1978) Methylene blue alters retention of inhibitory avoiddance responses Physiological Psychology 6, 387-390.

[148] Callaway NL, Riha PD, Bruchey AK, Munshi Z, GonzalezLima F (2004) Methylene blue improves brain oxidative metabolism and memory retention in rats. Pharmacol Biochem Behav 77, 175-181.

[149] Ramsay RR, Dunford C, Gillman PK (2007) Methylene blue and serotonin toxicity: inhibition of monoamine oxidase A (MAO A) confirms a theoretical prediction. Br J Pharmacol 152, 946-951.

[150] Dierks EA, Burstyn JN (1998) The deactivation of soluble guanylyl cyclase by redox-active agents. Arch Biochem Biophys 351, 1-7.

[151] Meissner PE, Mandi G, Witte S, Coulibaly B, Mansmann U, Rengelshausen J, Schiek W, Jahn A, Sanon M, Tapsoba T, Walter-Sack I, Mikus G, Burhenne J, Riedel KD, Schirmer H, Kouyate B, Muller O (2005) Safety of the methylene blue plus chloroquine combination in the treatment of uncomplicated falciparum malaria in young children of Burkina Faso [ISRCTN27290841]. Malar J 4, 45.

[152] Zacharakis N, Tone P, Flordellis CS, Maragoudakis ME, Tsopanoglou NE (2006) Methylene blue inhibits angiogenesis in chick chorioallontoic membrane through a nitric oxideindependent mechanism. J Cell Mol Med 10, 493-498.

[153] Boon EM, Barton JK (2003) DNA electrochemistry as a probe of base pair stacking in A-, B-, and Z-form DNA. Bioconjug Chem 14, 1140-1147.

[154] Carr HS, Winge DR (2003) Assembly of cytochrome c oxidase within the mitochondrion. Acc Chem Res 36, 309-316. 